\title{
Pengaruh Pengetahuan, Sikap, dan Perilaku Perawat tentang Flebotomi terhadap Kualitas Spesimen Laboratorium
}

\section{The Influence of Nurses' Knowledge, Attitude, and Behavior over Phlebotomy on Laboratory Specimen Quality}

\author{
Eky Indyanty $W^{1}{ }^{1}$, Harun Al Rasyid ${ }^{1}$, Armanu Thoyib ${ }^{2}$ \\ ${ }^{1}$ Program Studi Magister Manajemen Rumah Sakit Fakultas Kedokteran Universitas Brawijaya \\ Jurusan Manajemen Fakultas Ekonomi dan Bisnis Universitas Brawijaya
}

\begin{abstract}
ABSTRAK
Kesalahan pra-analitik memberikan kontribusi paling besar pada kesalahan di laboratorium (46-77,1\%). Pelaksanaan pengambilan spesimen (flebotomi) yang tidak tepat, kurangnya pengetahuan dan ketidakpatuhan dari petugas flebotomi dilaporkan sebagai penyebab kesalahan pra-analitik yang berhubungan dengan kualitas spesimen. Penelitian ini bertujuan untuk mengetahui pengetahuan, sikap, dan perilaku perawat tentang tindakan flebotomi serta pengaruhnya terhadap kualitas spesimen. Penelitian ini merupakan penelitian observasional analitik dengan pendekatan cross sectional. Populasi penelitian adalah 129 orang perawat pelaksana di Instalasi Rawat Inap RSUD Kabupaten Jombang dengan masa kerja minimal 1 tahun dipilih secara acak. Pengetahuan dan sikap responden tentang tindakan flebotomi diukur menggunakan kuesioner. Perilaku dan kualitas spesimen diukur melalui observasi dan wawancara. Analisis data yang digunakan adalah korelasi Spearman, independent sample t-test, dan multiple logistic regression. Terdapat korelasi positif yang bermakna antara pengetahuan perawat dan kualitas spesimen $(r=0,190 ; p=0,031)$. Tidak terdapat perbedaan bermakna rata-rata skor sikap perawat tentang flebotomi berdasarkan kualitas spesimen laboratorium $(p=0,698)$ dan tidak terdapat korelasi antara perilaku perawat dan kualitas spesimen $(r=0,017 ; p=0,846)$. Pengetahuan, sikap, dan perilaku perawat tidak berpengaruh terhadap perubahan kualitas spesimen, diduga faktor peralatan yang digunakan untuk flebotomi memiliki peran dalam penentuan kualitas spesimen. Peningkatan pengetahuan, mempertahankan sikap positif, memperbaiki sikap negatif serta merevisi SPO pengambilan darah perlu dilakukan untuk meningkatkan kualitas pelayanan.
\end{abstract}

Kata Kunci: Kesalahan pra-analitik, kualitas spesimen, pengetahuan, perawat, perilaku, sikap

\begin{abstract}
Pre-analytical errors contribute the biggest error portions in laboratory (46-77,1\%). Improper phlebotomy execution, lack of knowledge, and non compliance of nurses as phlebotomy officers were reported as the causes of pre-analytical errors related to specimen qualities. Objectives of this study are to find out the knowledge, attitudes, and behavior of nurses regarding phlebotomy as well as their effect on the specimen quality. This is an observational analytic study with cross sectional approach. The study population was 129 randomly selected inpatient nurses (with minimum working period of 1 year). Respondents' knowledge and attitudes about phlebotomy were measured using a questionnaire. Nurse's behavior and the specimen quality were measured through interviews and observation. Data analysis used were Spearman correlation, independent sample t-test, and multiple logistic regression. There was a significant positive correlation between nurses' knowledge and the quality of the specimen $(r=0,190 ; p=0,031)$. However, there was no significant difference in the average score of nurses' attitudes about phlebotomy based on the laboratory specimen quality $(p=0,698)$ and there was no correlation between the nurses' behavior and the specimen quality $(r=0,017 ; p=0,846)$. Knowledge, attitude, and behavior of nurses do not affect the changes in the specimen quality. It is suspected that equipment used for phlebotomy has a role in determining the specimen quality. Updating knowledge, maintaining positive attitudes, improving negative attitudes, and revising SOP for blood sampling must be executed to improve the service quality.
\end{abstract}

Keywords: Attitude, behavior, knowledge, nurse, pre-analytical error, quality of specimen

Jurnal Kedokteran Brawijaya, Vol. 28, No. 3, Februari 2015; Korespondensi: Eky Indyanty WL. Program Studi Magister Manajemen Rumah Sakit Fakultas Kedokteran Universitas Brawijaya, Jl. Veteran Malang (0341) 568989; Email: ekyindyanty@gmail.com 


\section{PENDAHULUAN}

Pelayanan laboratorium merupakan salah satu tulang punggung dari sektor pelayanan kesehatan. Laboratorium mempunyai tugas dan tanggung jawab penting sebagai penunjang pelayanan medis di rumah sakit dan diperkirakan memegang peranan sekitar 60-70\% terutama dalam hal penegakan diagnosis, tindak lanjut pengobatan, monitoring, keputusan rawat inap serta pasien pulang (1-3). Oleh karena itu peningkatan mutu pelayanan pemeriksaan laboratorium harus selalu terjamin dengan didasari quality management science (QMS) yang meliputi quality planning, quality laboratory practice, quality control, quality assurance, dan quality improvement. Mutu pemeriksaan laboratorium dapat didefinisikan sebagai derajat pemeriksaan yang sesuai dengan hasil pengukuran yang telah ditetapkan oleh laboratorium terhadap nilai sebenarnya dengan memperhatikan akurasi dan presisi (2).

Kemajuan yang pesat dalam bidang ilmu laboratorium saat ini belum dapat menghindarkan pemeriksaan laboratorium terhadap berbagai kesalahan. Kesalahan laboratorium didefinisikan sebagai setiap ketidaksesuaian mulai dari permintaan tes laboratorium sampai dengan pelaporan hasil dan interpretasi serta tindakan yang tepat dari hasil tersebut. Jenis kesalahan yang ditemukan di laboratorium diklasifikasikan sebagai kesalahan praanalitik, analitik, dan pasca-analitik (1). Beberapa penelitian melaporkan tingkat kesalahan laboratorium yang bervariasi, namun rata-rata tingkat kesalahan laboratorium yaitu tahap pra-analitik sebesar $46-77,1 \%$, tahap analitik sebesar $7-13 \%$, dan tahap pasca analitik sebesar 18,5-47\% (1,3-6).

Kesalahan tahap pra-analitik memberikan kontribusi paling besar pada kesalahan laboratorium (46-77,1\%). Beberapa hal yang termasuk kesalahan pra-analitik antara lain hemolisis $(53,2 \%)$, volume spesimen yang kurang $(7,5 \%)$, tulisan tangan yang tidak bisa dibaca $(7,2 \%)$, salah spesimen, spesimen ada bekuan, kesalahan vacuum container atau jenis antikoagulan, rasio volume spesimen dan antikoagulan yang tidak sesuai, spesimen darah diambil dari jalur infus (1,3-6). Data tersebut memperlihatkan bahwa kesalahan pra-analitik yang paling banyak yaitu kesalahan yang berhubungan dengan kualitas spesimen (hemolisis, volume spesimen kurang, spesimen ada bekuan, kesalahan vacuum container atau jenis antikoagulan, rasio volume spesimen dan antikoagulan yang tidak sesuai). Hal-hal tersebut merupakan indikator kualitas atau mutu pada tahap praanalitik di laboratorium (7).

udi pendahuluan pada bulan Desember 2013 di Instalasi Patologi Klinik Rumah Sakit Umum Daerah (RSUD) Kabupaten Jombang mengidentifikasi 25 kasus kesalahan yang berhubungan dengan kualitas spesimen dari 972 pengambilan darah pasien rawat inap (2,6\%). Jenis kesalahan tersebut antara lain spesimen beku (52\%), spesimen darah kurang (32\%), hemolisis (12\%), dan double sampling (4\%). Kualitas spesimen yang kurang memenuhi persyaratan tersebut dapat menyebabkan kesalahan hasil laboratorium yang akan menimbulkan kesalahan interpretasi hasil sehingga dapat menyebabkan kesalahan pengambilan keputusan pengobatan dan tindakan.

Pelaksanaan pengambilan spesimen darah (flebotomi) yang tidak tepat, kurangnya pengetahuan dan ketidakpatuhan dari petugas flebotomi dilaporkan sebagai penyebab kesalahan pra-analitik yang berhubungan dengan kualitas spesimen (1). Data mengenai tingkat pengetahuan, sikap, dan perilaku perawat di ruang rawat inap RSUD Kabupaten Jombang tentang tindakan flebotomi saat ini belum ada dan belum pernah dievaluasi. Penelitian ini bertujuan untuk mengetahui tingkat pengetahuan, sikap, dan perilaku perawat tentang tindakan flebotomi serta pengaruhnya terhadap kualitas spesimen laboratorium.

\section{METODE}

Penelitian ini merupakan penelitian observasional analitik dengan pendekatan cross sectional. Populasi penelitian ini adalah perawat pelaksana yang bertugas di Instalasi Rawat Inap RSUD Kabupaten Jombang yang sudah bekerja selama minimal 1 tahun. Sebanyak 129 perawat dipilih secara acak (simple random sampling) sebagai responden penelitian. Pengetahuan dan sikap responden tentang tindakan flebotomi diukur menggunakan kuesioner yang dikembangkan berdasarkan sumber buku ajar flebotomi $(8,9)$. Tingkat pengetahuan responden diukur berdasarkan persentase jawaban benar dari 14 item pertanyaan (dikatakan baik jika >75\% benar; cukup jika $\leq 56-74 \%$, dan kurang jika $<55 \%$ ) (10). Skor sikap responden diukur dari respon terhadap 6 item sikap dengan menggunakan 5 point Likert scale. Sebelum penelitian dilakukan, terlebih dahulu dilakukan uji validitas dan reliabilitas kuesioner. Perilaku (kepatuhan perawat terhadap standar prosedur operasional pengambilan sampel) diukur melalui observasi menggunakan checklist yang disusun berdasarkan standar operasional prosedur yang berlaku di RSUD Kabupaten Jombang. Kualitas spesimen laboratorium diukur berdasarkan hasil penilaian pakar di laboratorium klinik RSUD Kabupaten Jombang.

Uji multiple logistic regression digunakan untuk mengetahui pengaruh pengetahuan, skor sikap, dan perilaku perawat terhadap kualitas spesimen laboratorium. Uji korelasi digunakan untuk menganalisis hubungan antara tingkat pengetahuan dan kualitas spesimen. Untuk menganalisis hubungan antara perilaku perawat (patuh atau tidak patuh SPO) dan kualitas spesimen (layak atau tidak layak) digunakan uji statistik Chi-Square dengan tingkat kepercayaan 95\%. Independent sample t-test digunakan untuk analisis perbedaan skor sikap perawat tentang tindakan flebotomi berdasarkan kualitas spesimen.

\section{HASIL}

Hasil pada Tabel 1 menunjukkan bahwa mayoritas responden berjenis kelamin perempuan $(69,2 \%)$, rentang usia sekitar 31 tahun sampai dengan 40 tahun $(68,2 \%)$, dan pendidikan terakhir D3 Keperawatan (91,5\%). Masa kerja responden bervariasi dengan masa kerja terbanyak adalah 6 tahun sampai dengan 10 tahun $(38,8 \%)$ diikuti dengan masa kerja 11 tahun sampai dengan 15 tahun $(27,1 \%)$.

Tabel 1. Jumlah dan karakteristik responden penelitian

\begin{tabular}{lcc}
\hline \multicolumn{1}{c}{ Variabel } & n & Persentase \\
\hline Jenis kelamin: & & \\
Laki-laki & 39 & 30,2 \\
Perempuan & 90 & 69,8 \\
\hline
\end{tabular}


Tabel 1. Jumlah dan karakteristik responden penelitian (Lanjutan)

\begin{tabular}{lrc}
\hline \multicolumn{1}{c}{ Variabel } & $\mathbf{n}$ & Persentase \\
\hline Usia: & 34 & 26,4 \\
21-30 tahun & 88 & 68,2 \\
31-40 tahun & 7 & 5,4 \\
41-50 tahun & & \\
Pendidikan: & 118 & 91,5 \\
D3 Keperawatan & 3 & 2,3 \\
D4 Keperawatan & 8 & 6,2 \\
S1 Keperawatan & & \\
Masa kerja: & 32 & 24,8 \\
1-5 tahun & 50 & 38,8 \\
6-10 tahun & 35 & 27,1 \\
11-15 tahun & 10 & 7,8 \\
16-20 tahun & 2 & 1,6 \\
21-25 tahun & &
\end{tabular}

Sumber: Data kuesioner diolah 2014

Tabel 2 menunjukkan bahwa mayoritas responden $(60,5 \%)$ mempunyai pengetahuan yang kurang dan hanya $4,7 \%$ responden yang mempunyai pengetahuan baik tentang flebotomi. Tingkat kepatuhan responden terhadap standar prosedur operasional pengambilan sampel darah di RSUD Kabupaten Jombang masih baik $(89,1 \%)$. Kualitas spesimen darah di laboratorium Instalasi Patologi Klinik RSUD Kabupaten Jombang sekitar 8,5\% dinilai tidak layak antara lain sampel mengalami hemolisis, volume kurang, dan sampel ada bekuan.

Tabel 2. Pengetahuan, perilaku, kualitas spesimen laboratorium, dan kualitas spesimen laboratorium tidak layak

\begin{tabular}{lrr}
\hline \multicolumn{1}{c}{ Variabel } & $\mathbf{n}$ & Persentase \\
\hline Pengetahuan: & & \\
Baik & 6 & 4,7 \\
Cukup & 45 & 34,9 \\
Kurang & 78 & 60,5 \\
Perilaku: & & \\
Patuh terhadap SPO & 115 & 89,1 \\
Tidak patuh terhadap SPO & 14 & 10,9 \\
Kualitas spesimen: & & \\
Layak & 118 & 91,5 \\
Tidak layak & 11 & 8,5 \\
Indikator kualitas spesimen: & & \\
Spesimen hemolisis & 2 & 18,2 \\
Spesimen beku & 2 & 18,2 \\
Volume kurang & 7 & 63,6 \\
Kesalahan antikoagulan & 0 & 0 \\
\hline
\end{tabular}

Sumber: Data diolah 2014

SPO: Standar Prosedur Operasional

Mayoritas responden memiliki sikap setuju (85,3\%) bahwa tindakan penekanan yang berlebihan pada plunger atau karet spuit saat memasukkan darah ke tabung spesimen dapat menyebabkan hemolisis. Responden juga setuju $(88,4 \%)$ bahwa jenis dan fungsi antikoagulan perlu diketahui dengan benar serta tindakan pembendungan pada lengan saat pengambilan darah jangan terlalu lama (94,6\%). Responden tidak setuju terhadap beberapa pernyataan yang bersifat negatif antara lain adanya bekuan dalam spesimen darah dapat diatasi dengan cara mengambil bekuan tersebut dari tabung $(81,4 \%)$, pengambilan spesimen darah dari jalur infus $(73,7 \%)$, serta volume darah yang kurang tidak mempengaruhi pemeriksaan laboratorium (71,3\%).

Penelitian ini menunjukkan bahwa terdapat korelasi positif yang bermakna antara pengetahuan perawat tentang flebotomi dan kualitas spesimen, namun kekuatan korelasinya lemah $(r=0,190 ; p=0,031)$. Artinya semakin tinggi pengetahuan perawat tentang flebotomi maka semakin baik kualitas spesimen. Hasil uji regresi logistik menunjukkan bahwa tingkat pengetahuan perawat tentang flebotomi hanya mampu menjelaskan perubahan kualitas spesimen sebesar $10,1 \%$ tetapi pengaruh perubahan tersebut tidak signifikan $(p=0,216)$.

Rata-rata skor sikap perawat tentang flebotomi berdasarkan kualitas spesimen laboratorium ditemukan tidak berbeda bermakna $(p=0,698)$. Skor sikap responden yang bisa menunjukkan kualitas spesimen layak tidak berbeda dengan skor sikap responden yang menunjukkan kualitas spesimen yang tidak layak. Hasil uji regresi logistik menunjukkan pengaruh sikap perawat tentang tindakan flebotomi hanya mampu menjelaskan perubahan variabel kualitas spesimen sebesar $0,3 \%(p=0,695)$.

Penelitian ini juga mendapatkan bahwa tidak terdapat korelasi antara perilaku perawat saat tindakan flebotomi dan kualitas spesimen $(r=0,017 ; p=0,846)$. Hasil uji regresi logistik menunjukkan bahwa pengaruh perilaku perawat saat tindakan flebotomi hanya mampu menjelaskan perubahan kualitas spesimen sebesar $0,1 \%$ dan pengaruh perubahan tersebut tidak signifikan $(p=0,845)$.

\section{DISKUSI}

Mayoritas kualitas spesimen darah yang dihasilkan dari tindakan flebotomi para responden dinilai layak dan memenuhi persyaratan (91,5\%). Bila dibandingkan dengan penelitian sebelumnya yang mendapatkan data kesalahan pra-analitik yang berhubungan dengan kualitas spesimen sebesar $60,7 \%$ (1), tingkat kesalahan pra-analitik yang disebabkan oleh spesimen tidak layak di Instalasi Patologi Klinik RSUD Kabupaten Jombang dapat dikatakan masih relatif rendah.

Tahap pra-analitik, terutama saat pengambilan darah (spesimen collection), sangat penting untuk diperhatikan karena berhubungan dengan patient safety dan patientcentered care. Kesalahan pada tahap pra-analitik akan berdampak pada kesalahan analisis hasil pemeriksaan sehingga dapat menimbulkan kesalahan interpretasi hasil dan tata laksana pasien yang tidak tepat (11). Kesalahan pada tahap pra-analitik juga dapat menimbulkan tambahan pemeriksaan laboratorium atau pemeriksaan lainnya yang tidak diperlukan oleh pasien. Hal ini dapat menyebabkan penambahan biaya pada sistem pelayanan kesehatan (12).

Pengetahuan responden tentang flebotomi berhubungan dengan kualitas spesimen yang dihasilkan saat flebotomi $(p=0,031)$. Semakin tinggi pengetahuan responden maka kualitas spesimen yang dihasilkan semakin baik $(r=0,190)$. Walaupun ditemukan adanya hubungan namun tidak ada pengaruh pengetahuan terhadap kualitas spesimen $(p=0,216)$. Pengetahuan hanya memberi kontribusi $10,1 \%$ terhadap perubahan kualitas spesimen. Hal ini menunjukkan bahwa pengaruh perubahan kualitas spesimen berasal dari faktor lain selain pengetahuan 
$(89,9 \%)$. Temuan penelitian ini tidak mendukung dugaan hasil penelitian yang dilakukan oleh Goswami et al yang menyatakan bahwa pelaksanaan flebotomi yang tidak tepat, kurangnya pengetahuan dan ketidakpatuhan dari petugas flebotomi merupakan penyebab kesalahan praanalitik yang berhubungan dengan kualitas spesimen (1).

Laboratorium harus mendapatkan spesimen dengan kualitas yang baik agar hasil yang dikeluarkan dapat menggambarkan kondisi pasien yang sebenarnya dan menghasilkan mutu yang lebih baik (13). Oleh karena itu pengetahuan yang baik tentang flebotomi harus dikuasai oleh petugas flebotomi. Penelitian yang dilakukan sebelumnya dengan tujuan untuk mencari korelasi antara pengetahuan dan kualitas pelayanan mendapatkan bahwa pengetahuan yang baik tentang pencegahan dan pengobatan ulkus dapat mempengaruhi kualitas pelayanan yang diberikan kepada pasien $(14,15)$. Penelitian lain mendapatkan hasil bahwa kurangnya pendidikan dan pengetahuan perawat dianggap sebagai hambatan untuk pelayanan tata laksana nyeri (16). Penelitian tersebut menunjukkan bahwa pengetahuan yang baik sangat mempengaruhi kualitas pelayanan. Demikian juga pelayanan di laboratorium, pengetahuan yang baik tentang flebotomi mempengaruhi kualitas spesimen. Oleh karena itu peningkatan pengetahuan tentang flebotomi perlu mendapat perhatian khusus.

Penelitian ini juga mendapatkan bahwa tidak ada hubungan yang bermakna antara sikap perawat tentang flebotomi dengan kualitas spesimen laboratorium $(p=0,698)$. Secara keseluruhan, responden sudah mempunyai sikap yang baik tentang flebotomi. Mayoritas responden mempunyai sikap yang positif terhadap hal-hal yang dapat menyebabkan kesalahan pra-analitik laboratorium yang akan mempengaruhi kualitas spesimen yang dihasilkan saat flebotomi. Oleh karena itu perlu dilakukan upaya mempertahankan sikap positif dan memperbaiki sikap negatif agar kesalahan pra-analitik yang disebabkan oleh kualitas spesimen dapat dikurangi.

Penelitian ini mendapatkan hasil tidak ada korelasi antara perilaku perawat saat tindakan flebotomi dan kualitas spesimen $(r=0,017 ; p=0,846)$. Hal ini kemungkinan disebabkan oleh Standar Prosedur Operasional (SPO) pengambilan spesimen yang digunakan untuk menilai perilaku (kepatuhan responden) belum menggambarkan SPO yang sudah standar sehingga belum bisa menjelaskan hubungannya dengan kualitas spesimen. Selain itu peralatan flebotomi di ruang rawat inap RSUD Kabupaten Jombang sebagian belum terstandarisasi, sehingga dapat diduga bahwa faktor peralatan yang digunakan justru lebih memiliki peran dalam penentuan kualitas spesimen.

Penelitian sebelumnya mendapatkan hasil bahwa

\section{DAFTAR PUSTAKA}

1. Goswami B, Singh B, Chawla R, and Mallika V. Evaluation of Error in a Clinical Laboratory: A OneYear Experience. Clinical Chemistry and Laboratory Medicine. 2010; 48(1): 63-66.

2. Kahar H. Peningkatan Mutu Pemeriksaan di Laboratorium Klinik Rumah Sakit. Indonesian Journal of Clinical Pathology and Medical Laboratory. 2005; 12(1): 38-40. penggunaan tabung penampung spesimen darah disposable yang sudah terstandarisasi (evacuated blood collection system) dapat memberikan kualitas spesimen pra-analitik yang lebih baik dibandingkan dengan sistem jarum suntik atau syringe dan tabung penampung botol kaca yang dicuci kembali (re-washed glass vial). Hasil penelitian tersebut mendapatkan bahwa penggunaan evacuated blood collection system yang sudah terstandarisasi dapat menurunkan insiden spesimen beku (70 kali lipat lebih rendah), spesimen hemolisis (100 kali lipat lebih rendah), volume spesimen yang kurang (200 kali lipat lebih rendah), kontaminasi spesimen (10 kali lipat lebih rendah), dan spesimen tumpah $(17,18)$. Sebagian ruang rawat inap di RSUD Kabupaten Jombang masih menggunakan botol penampung kaca yang dicuci kembali untuk tempat penampung spesimen darah. Oleh karena itu pemakaian evacuated blood collection dianjurkan agar dapat menurunkan atau menghindarkan tingkat kesalahan pra-analitik yang disebabkan oleh spesimen hemolisis, volume spesimen kurang, dan spesimen ada bekuan. Jika evacuated blood collection sulit disediakan, maka perlu dilakukan sosialisasi dan pelatihan kepada perawat tentang jenis antikoagulan serta rasio darah dan antikogulan yang benar.

Clinical Laboratory Standard Institute (CLSI) telah menyusun dokumen yang disebut sebagai CLSI H03-A6 tentang Procedures for the Collection of Diagnostic Blood Spesimens by Venipuncture yang mampu meningkatkan kualitas prosedur pengambilan darah. Pelaksanaan dari dokumen CLSI H03-A6 tersebut dapat meningkatkan mutu proses laboratorium di daerah Amerika Selatan $(12,19)$. Dokumen ini dapat digunakan sebagai acuan rumah sakit untuk menyusun SPO tentang pengambilan darah sehingga lebih terstandarisasi. Keterbatasan penelitian ini dilakukan secara cross sectional yaitu menganalisis variabel independen dan dependen pada satu kali pengamatan saja sehingga kemungkinan ada kesalahan yang bisa mengurangi akurasi hasil penelitian. Oleh karena itu untuk penelitian selanjutnya diperlukan pengamatan dan pengukuran yang serial terhadap pengetahuan, sikap, perilaku, dan kualitas spesimen sehingga didapatkan hasil yang lebih akurat.

Pengetahuan, sikap, dan perilaku perawat tidak berpengaruh terhadap perubahan kualitas spesimen, diduga faktor peralatan yang digunakan untuk flebotomi serta faktor pengalaman kerja yang cukup lama memiliki peran dalam penentuan kualitas spesimen. Updating pengetahuan, mempertahankan sikap positif, memperbaiki sikap negatif serta merevisi SPO pengambilan darah perlu dilakukan untuk mempertahankan sikap dan perilaku positif perawat dalam proses pengambilan sampel pemeriksaan laboratorium.

3. Rin GD. Pre-Analytical Workstations: A Tool For Reducing Laboratory Errors. Clinica Chimica Acta. 2009; 404(1): 68-74.

4. Bonini P, Plebani M, Ceriotti F, and Rubboli F. Errors in Laboratory Medicine. Clinical Chemistry. 2002; 48(5): 691-698.

5. Hawkins R. Managing the Pre- and Post- Analytical Phases of the Total Testing Process. Annals of Laboratory Medicine. 2012; 32(1): 5-16. 
8. Ernst DJ. Applied Phlebotomy. Baltimore: Lippincott Williams \& Wilkins; 2005.

9. Garza D and Becan-McBride K. Phlebotomy Handbook: Blood Collection Essentials. New Jersey: Pearson Education; 2002.

10. Budiman dan Riyanto A. Kapita Selekta Kuesioner: Pengetahuan dan Sikap dalam Penelitian Kesehatan. Jakarta: Salemba Medika; 2013.

11. Lippi G, Becan-McBride K, Behulova D, et al. Preanalytical Quality Improvement: In Quality We Trust. Clinical Chemistry and Laboratory Medicine. 2013; 51(1): 229-241.

12. Lima-Oliveira G, Lippi G, Salvagno GL, Montagnana M, Picheth G, and Guidi GC. Impact of the Phlebotomy Training Based on CLSI/NCCLS H03-A6-Procedures for the Collection of Diagnostic Blood Spesimens by Venipuncture. Biochemia Medica. 2012; 22(3): 342351.

13. Sirisali K, Manochiopinij S, Vattanaviboon P, Sirisali S, Wonglumsom W. The Training of Dual Professionals Via Evidence-Based Learning. Royal Thai Army Medical Journal. 2012; 65: 185-191.

14. Haram R, Ribu E, and Rustoen T. The Views of District Nurses on Their Level of Knowledge about the Treatment of Leg and Foot Ulcers. Journal of Wound,
Ostomy and Continence Nursing. 2003; 30(1): 25-32.

15. Källman U and Suserud BO. Knowledge, Attitudes and Practice among Nursing Staff Concerning Pressure Ulcer Prevention and Treatment-a Survey in a Swedish Healthcare Setting. Scandinavian Journal of Caring Sciences. 2009; 23(2): 334-341.

16. Rejeh N, Ahmadi F, Mohammadi E, Kazemnejad A, and Anoosheh M. Nurses' Experiences and Perceptions of Influencing Barriers to Postoperative Pain Management. Scandinavian Journal of Caring Sciences. 2009; 23(2): 274-281.

17. Ashavaid TF, Dandekar SP, Khodaiji S, Ansari MH, and Singh AP. Influence of Method of Spesimen Collection on Various Preanalytical Sample Quality Indicators in EDTA Blood Collected for Cell Counting. Indian Journal of Clinical Biochemistry. 2009; 24(4): 356-360.

18. Ashavaid TF, Dandekar SP, Keny B, and Bhambhwani VR. Influence of Blood Spesimen Collection Method on Various Preanalytical Sample Quality Indicators. Indian Journal of Clinical Biochemistry. 2008; 23(2): 144-149.

19. Ernst DJ, Ballance LO, Calam RR, et al. Procedures for the Collection of Diagnostic Blood Spesimens by Venipuncture; Approved Standard-Sixth Edition. Pennsylvania: Clinical and Laboratory Standards Institute; 2007 